\title{
Stakeholder Perceptions on Achieved Benefits of PFI Procurement Strategy
}

\author{
Abdullahi A. Umar ${ }^{1}$, Noor Amila Wan Abdullah Zawawi ${ }^{1}$, Mohd Faris Khamidi ${ }^{1}$ \& Arazi Idrus ${ }^{2}$ \\ ${ }^{1}$ Dept. of Civil Engineering, Universiti Teknologi PETRONAS, Bandar Seri Iskandar, Tronoh, Perak, Malaysia \\ ${ }^{2}$ Dept. of Civil Engineering, Universiti Pertahanan Nasional Malaysia, Kem Sg. Besi, Kuala, Lumpur, Malaysia \\ Correspondence: Abdullahi A. Umar, Dept. of Civil Engineering, Universiti Teknologi PETRONAS, Bandar \\ Seri Iskandar, Tronoh 31750, Perak, Malaysia. Tel: 60-17-461-5710. E-mail: abdulproject@yahoo.com
}

Received: August 9, 2012

Accepted: February 27, $2013 \quad$ Online Published: March 13, 2013

doi:10.5539/mas.v7n4p31

URL: http://dx.doi.org/10.5539/mas.v7n4p31

\begin{abstract}
The Private Finance Initiative (PFI) has become the most acceptable strategy employed by governments across the globe for the provision of the much needed public infrastructure. Many benefits have been attributed to this form of public procurement while it has also received several criticisms. This study sets out to assess if the benefits attributed to the PFI are being achieved. Survey questionnaires were used to get the perception of delegates from different regions who attended two (2) PFI-focused conferences held independently by two different organisations. The results of the survey are presented in the study. Generally, most of the respondents agreed that the benefits of PFI are being reaped across the globe with 'helping government spread payment over the life of the asset', 'increased investment in infrastructure', 'on-time delivery', 'contribution to economic growth', and 'on-budget delivery' being the most significant achievements so far and surprisingly 'providing value for money' ranking in faraway $17^{\text {th }}$ place out of 20 benefits listed.
\end{abstract}

Keywords: PFI, benefits, strategy, value for money, public procurement

\section{Introduction}

The provision of quality public infrastructure and services forms an important aspect of a government's duty to its citizens. This is because it forms the basis upon which individuals achieve their economic aims and also helps raise the standard of living of the society. Successful countries provide economy and society with infrastructure needed to maintain growth (Thanh \& Dapice, 2009). Public infrastructures are also a pre-requisite for the flow of Foreign Direct Investments (FDIs). Development experience suggests that investing 7\% of GDP in infrastructure is the right order of magnitude for high and sustained growth (World Bank, 2007). However, the provision of these services is based on the efficiency and effectiveness of the construction industry, the availability of public finances and the general strategic economic policy of the government. In the past, governments funded all public infrastructures from tax revenue and contracted private contractors to build the infrastructure while the government through its public service and civil servants operated the assets, though maintenance was also contracted out whenever the need arose to carry out maintenance works. However, the poor quality of the constructed assets raised a lot of issues and the lack of maintenance culture in the public sector led to poor public services which resulted in road congestions, poor health services, poor train services and inability to meet Universal Service Obligations (USO) in network utilities such as water and electricity. This led governments around the world to seek for better ways to provide these basic services. In the UK for instance, recognising the need for better infrastructure, the UK government commissioned several inquiries on how to overcome the problems of poorly constructed assets. These inquiries resulted in the Simon (1944) report, Emerson (1962) report, Latham (1994) report, Egan (1998) report and Modernising Construction by NAO (2000). Generally, summarising the findings of all the various reports hinted at the followings:

1) The industry was fragmented;

2) Existence of adversarial relationships;

3) Need to foster trust between clients and contractors;

4) The need to develop a collaborative culture; 
5) Recommended new educational standard;

6) Recommendation for reduction in construction costs over time;

7) Lower life-cycle and operational costs;

8) Elimination of waste in labour and materials;

9) Greater certainty of project time and costs;

10) Departments to increase training for staff in procurement and risk management;

11) Improve health and safety record in construction.

In relation to improving collaborative efforts, it was Latham and Egan who made reference to the issue of partnering though not in the context of the PFI. "Partnering", Latham (1994) observed, "includes the concepts of teamwork between supplier and client, and of total continuous improvement. It requires openness between the parties, ready acceptance of new ideas, trust and perceived mutual benefit.... We are confident that partnering can bring significant benefits by improving quality and timeliness of completion whilst reducing costs." However, in spite of these reports, things did not progress as expected. The problem of sufficient tax revenue to pay for the provision of constructed public assets coupled with the need to transfer risks to the contractors, margin erosion in the face of stiff competition among contractors and the pressure from International Financial Institutions (IFIs) especially in developing countries to adopt market mechanisms gave birth to what is today known as the Private Finance Initiative (PFI) or Public-Private Partnerships (PPP) in some regions. The PFI is a subset of the public sector reforms sweeping across the globe in the form of New Public Management (NPM). The NPM is the attempt to implement management ideas from business and private sector into the public services (Haynes, 2003). While not an entirely new procurement strategy, having been used in France in 1782, Suez Canal in 1856, Hong Kong in the early 1950s, Turkey in the form of Build Operate Transfer (BOT) in 1982 and Australia in 1988, it was 're-invented' in the UK in 1992. Most modern writers now attribute the strategy to the UK in many academic literatures, however, this may not be unconnected with the fact that "while the use of PPPs has spread to most EU Member States, the UK is still the largest and most diverse PPP market" (Thomson \& Goodwin, 2005). The advent of this procurement strategy has generated lots of debates especially among researchers, the public and trade unions with UNISON in the UK being perhaps the most vocal so far. On the other hand, in spite of all the criticisms, governments have persisted with its adoption and continue to enter into newer contracts. The debates about its benefits continue to rage on with no clear evidence that all the benefits expected are being achieved. Rather, there is a continuous shifting of the goals of the PFI by different governments each time an espoused reason is attacked by the wary public. There are a number of studies and reports written to highlight the benefits of PFI. Top among these is the report by Arthur Andersen Enterprise titled 'Value for Money Drivers in the Private Finance Initiative' which incidentally was commissioned by Treasury Taskforce and others by the National Audit Office. However, as soon as these reports reached the public sphere, writers opposed to PFI began to pick holes in them and some of the criticisms seem to be well founded. This study seeks to assess to what extent the benefits of the PFI have been achieved or are being achieved, through the use of a survey questionnaire to get the perceptions of those involved with the PFI, in both the public and private sector, on the benefits that have been derived from the adoption of the PFI strategy. The study also intends to rank these supposed benefits in order of importance to assess the most important according to the perception of the respondents. This study also echoes the observations of Hodge and Greve (2005) that "There is now a critical need to review the experiences with PPPs as they have evolved throughout the world". This study, admittedly, is not the first that has intended to assess if the benefits of PFI are being achieved. Hodge and Greve (2009) in their study 'PPPs: The Passage of Time Permits a Sober Reflection' argue that evaluations of PPP has shown contradictory results regarding their effectiveness and value for money (VFM) and suggested that greater care was required to strenghten future evaluation and such an evaluation should be conducted away from the policy chearleaders. But their work did not involve a survey, instead they undertook a review. Palmer (2000) in his report prepared for the IPPR commision on PPP, titled "Contracting Issues and Financing in PPP/PFI (Do we need the 'F' in Design Build, Finance \& Operate (DBFO) projects", also assessed the practice of PFI, questioning the need for private finance and suggesting the use of Design, Build and Operate (DBO) while the public sector which had access to cheaper financing should provide the financing. His study also involved a review. Estache (2005) also conducted a review of the state of PPPs in the least developed countries (LDCs) and argues that the wide differences in interpretations of the facts regarding PPPs could be explained by the differences in assessment criteria employed by analysts, and is also affected by sectors, the regions and most importantly the major players upon whom the analysis tends to focus. He concluded that once all these factors are assessed objectively, only then would a 'relatively fair and quantitative assessment of the prospects of the 
public-private relationship in infrastructure be possible'. That being said, this study is different in that it was not targeted at a particular sector, region or stakeholders. This study also scored a first in that the survey questionnaires were target at participants and delegates from both the public and private sectors who attended two (2) infrastructure focused conferences in Kuala Lumpur, Malaysia in the months of March and April 2012. The two conferences combined had over 200 delegates from 28 countries in attendance. The survey sought to get their perceptions regarding the extent to which the perceived benefits of PFI were being achieved.

\subsection{The PFI Manifesto: Where Should We Vote?}

There is no doubt that the PFI procurement strategy has had the impact of delivering projects faster than would otherwise have been possible relying on public tax revenue alone. However, the concept of PFI has faced strong criticisms from those who see it as another name meant to reduce the dislike for the word 'privatisation' due to the experiences witnessed under the privatisation policy in many countries; however, other commentators including the governments and multi-lateral institutions such as the World Bank and IMF, continue to promote market mechanisms for the provision of public services and infrastructures. Both sides of the divide have had plausible evidence to support their various stand. It is important that the original reasons for the adoption of this procurement route be assessed to ascertain if the purported benefits are being reaped. Corner (2006) argues that "private finance initiatives (PFI) contracts can deliver better value for money (VFM) than traditional methods of procurement if risks are transferred to the parties best able to handle them". This begs the question of what these risks that must be transferred are. The essential risks said to be transferred under the PFI are mainly construction risks i.e. time and cost overruns, design risks, whole life costs risks; financial risks and service delivery risks. But these have not been substantiated through any known independent investigation except for the Arthur Andersen report, Value for Money Drivers in the Private Finance Initiative, commissioned by the Treasury Taskforce in the UK, which many commentators like Pollock, Shaoul, and Vickers (2002) have criticised for being biased in favour of the PFI. In fact government outside the UK cite the UK government's own reasons which are being challenged back home as the reason for adopting the procurement option as they cannot come up with any other precedent to support their obsession with the PFI. There are no publicly available data from any government around the globe to support the use of PFI over the traditional procurement route. This position was also supported by UNISON Scotland (2007) who observed that "Obsessive secrecy and claims of commercial confidentiality have meant that it has often been difficult or impossible to obtain figures to properly assess the validity of value for money claims". Relevant documents have frequently either not been published or have had key financial information withheld. Shaoul, Stafford, and Stapleton (2012) argue that there is a need for information to be accessible to the public, and in particular a stream of information between the public and private sector partners needs to be developed and disseminated to achieve accountability for public money that is increasingly spent in the private sector. Apart from the VFM and other construction risks being cited as reasons for adopting PFI, Connoly, Reeves and Wall (2009) assessing the reasons why PFI is still being pursued in the Republic of Ireland and Northern Ireland despite the negative vibes from neighbouring countries, concluded that "policy makers persist with them due to 'coercive isomorphic pressures' in the case of Northern Ireland and 'mimetic isomorphic pressures' in the case of Republic of Ireland". The obsession with PFI has even led the government of British Columbia in Canada to create a self-inflicted financial crisis just to get the public to support its bid to adopt the PFI as the main procurement strategy for public services (Cohn, 2008).

In terms of cost, a study by Blanc-Brude, Goldsmith and Valila (2009) concluded that the PFI was $24 \%$ more expensive than the traditional procurement route but was quick to add that the higher cost reflected the risks being shouldered by the private sector. But experiences on some notable PFI projects such as METRONET, London underground, reveals that the said risks were never really transferred as the public sector had to come to the aid of most of concessionaires to save the various projects from going under due to the consequences of failure and the political costs associated with it. Many reasons have been advanced for the adoption of this procurement route and these include but not limited to, pressure on public finances (Asenova \& Beck, 2010), faster provision of services than would have been possible relying solely on the government (Parker \& Hartley, 2003), private sector expertise, innovations and operational efficiency (Zhang \& Kumaraswamy, 2001; Siang, 2008), technology transfer (Li, Akintoye, Edwards, \& Hardcastle, 2005), value for money (VFM) (Parker \& Hartley, 2003; Cartlidge, 2004) and costs savings (The Commission on PPP, 2001). The extent to which these espoused benefits are true remains to be ascertained because most studies that have tried to prove the superiority of the PFI over the traditional procurement route have been criticized for either using a smaller sample of PFI or traditional projects in their analysis, or the criteria used in the selection of projects reviewed were flawed or the methodology was not all encompassing. Maltby (2003) observed that he had doubts on the reported $15 \%$ savings for roads and prisons reported by the Commission on PPP (2001), pointing out that of the 378 PPPs completed 
by central and local government by 2002 only 23 projects representing $6 \%$ had been subjected to an 'independent' VFM assessment. The said report by the Commission on PPPs observed further that for projects in the education and health sectors, the savings were not that significant and fell within a range of approximately 2-4\%. Also in an updated report on the Construction Performance of PFI (NAO, 2009) observed in terms of time and cost performance, the PFI delivered on time $69 \%$ of the time and on cost $65 \%$ and surprisingly the major cause of delays faced was 'private sector' project management issues constituting a whopping $42 \%$ of the causes of delays. When all other problems that were attributed to the private sector are aggregated, it brings the total percentage of delay causes that can be attributed to the private sector under the PFI to $66 \%$. What is often neglected and has not been researched is the fact that these same construction firms involved in PFI were in most cases the same ones who faced delays and cost overruns under the traditional procurement process. The same issues of inadequate skills, labour shortages $(\mathrm{NAO}, 2001)$ and a decline in enrolment into construction related courses causing the public and private sectors to rely on not-too skilled personnel still persist under the PFI environment, resulting in the current project management issues. However, other procurement routes can still do the same or better if properly managed. What the causes of private sector delays in PFI reported by NAO (2009) simply highlight is the absence of experienced project managers. It appears that once a government makes up its mind to adopt the PFI, not even scientific evidence to the contrary can stop them. UNISON Scotland (2007) reports a very interesting occurrence on the East Ayrshire Community Hospital PFI, where the Full Business Case (FBC) for East Ayrshire Community Hospital in 1996 concluded that the PFI option did not offer VFM as it was $£ 1.7 \mathrm{~m}$ more than the Public Sector Comparator (PSC). However, in 1997 an FBC addendum was incorporated with various adjustments which helped reduce the difference between the PFI and PSC to $£ 11,000$ still in favour of the PSC. But the Trust said: "The small margin by which the NPV of the PFI bid exceeds the risk-adjusted PSC leads the Trust to the conclusion that the PFI option offers value for money."

The first wave PFI projects in the UK were contracted in the belief that the PFI would help managed the twin evils of cost and time overruns and also reduce whole-life costs. Sciulli (2007) also argues that "under the traditional procurement methods, governments had to contend with the risk of significant cost overruns for large infrastructure projects. This risk is now mitigated under the PPP as the private sector partner assumes this risk". But this argument seems flawed in the light of existing practices in the construction industry where the contractor is already given incentives that would help overcome these two risks through the inclusion of Liquidated and Ascertained Damages (LADs) clauses in all known conditions of contracts employed in the industry internationally. Perhaps what is not highlighted in the course of the blames heaped on the inefficiency of the traditional procurement route has always been that "most delays are partially the fault of the (clients) owners (Hinze, 2001) and these could come in the form of delays in approvals for relevant works, delays by the client representatives in preparing interim certificates to facilitate payments on account to the contractor. Client introduced variations have also been known to contribute to delays under the traditional procurement route and the link between delays and cost overruns have been established by previous researchers (Sambasivan \& Soon, 2007; Aibinu \& Jagboro, 2002; Ali, Smith, Pitt, \& Choon, 2010; Pourrostam \& Ismail, 2011). In a related study on the causes of delays, Assaf and Al-Hejji (2006) found that the most common cause of delay in large construction projects was 'change order' which again is a factor determined by the client. Therefore instead of taking a retrospective view to correct the anomalies in the traditional procurement, governments across the world opted for the 'newly' discovered procurement route, the PFI.

Budds and McGranahan (2003) in their study on the water and sanitation sectors in Africa, Asia and Latin America, were pessimistic about the role that privatization can play in achieving the Millennium Development Goals (MDGs) of halving the number of people without access to water and sanitation by 2015. This pessimism they contend does not arise from the prominent conflict of interest between private profits and the public good, but because some of the barriers to efficiency of water provision like land tenure systems still persists and it is suspicious that despite earlier failures of privatisation in history, international financial institutions and large water corporations like Suez continue to push for greater private involvement in water provision. They conclude by observing that "privatization has achieved neither the scale nor benefits anticipated". The Cochabamba experience reported by Nickson and Vargas (2002), Indah Water Konsortium reported by Abdul-aziz (2001) and the Buy-backs reported by UNISON Scotland (2007) of the Skye Bridge (bought back at $£ 26.7$ million), the Inverness Airport (bought back in 2005 at $£ 25$ million only $1.6 \%$ cheaper than PSC figures), and the West Lothian College bought back at great cost to taxpayers have all further served to dwarf the supposed benefits of the PFI procurement. Mehra (2005) has also attacked the purported benefits of the PFI arguing that "democratic control has been sacrificed to commercial secrecy and private for profit management; high costs have led to service cuts and diminished access. She also supported her assertions with a list of 100 PFI projects in Canada, Australia and the UK which have faced at least one of the risks the PFI was said to prevent (time overruns, cost 
overruns, service cuts, design problems, high cost of services etc). The increasing failures to achieve what the PFI was purported to be able to achieve may perhaps have led to KPMG (2010) stating that "increased private sector involvement is not a total solution and the public sector should also bear responsibility for how it leverages the private sector to best add value". And finally, according to Rashid (2007) "notwithstanding the many critiques of PFI, the mushrooming of PFI and other PPP projects worldwide suggests that PFI and PPP are here to stay" while Maltby (2003) concluded that "in the current political climate, the PFI is likely to remain primarily for construction. The Government is wary about relying on contracts alone to secure the public interest for complex and high profile services". The question that remains on the lips of many is why the governments across the globe still persist in adopting this procurement approach despite the volume of evidence that has been generated from operational PFI projects globally. Are the promised benefits being reaped and do the stakeholders perceive that these benefits are being achieved.

\section{Research Methodology}

An in-depth literature review was carried out to identify the basic assumptions upon which governments have decided to adopt the PFI procurement strategy. The literature review was undertaken in the belief that knowledge accumulates and one can learn from and build on what others have done in the past (Webster \& Watson, 2002). The review also included the basis upon which those opposed to the PFI have based their arguments. A survey questionnaire was designed based on the identified supposed benefits of PFI from literature. In total 20 benefits of PFI were identified from the literature and included in the survey questionnaire. The questionnaires were distributed to delegates that attended $2 \mathrm{PFI} /$ infrastructure-focused conferences in Kuala Lumpur, Malaysia. The conferences took place in March and April 2012 drawing together over 200 combined delegates from 28 countries. These delegates consisted of independent infrastructure consultants, public and private sector practitioners of PFI. A total of 200 questionnaires were distributed by placing them on the tables provided for the delegates with the permission of the organisers. However, some left theirs in their hotel rooms and requested for fresh copies the next day. At the end of the two conferences, 35 of the questionnaires were retrieved without being filled, 44 were returned completely filled out while 121 were unaccounted for. Deducting 35 unfilled from 200 gives a balance of 165 out of which 44 were filled and 121 neither filled nor returned. If we base the distributed questionnaires on the 165 , then a return rate of about $26 \%$ was achieved. This is comparable with Proverbs, Holt, and Olomoaiye (1999)'s 21\% achieved in the UK. The collected data were entered into SPSS statistical software version 17.0 and analysed to draw inferences, while the relative importance index (RII) was used to rank the benefits as perceived by the respondents. The index generates values from 0 to 1 and the closer to $1 \mathrm{a}$ value gets, the more important it is perceived to be. The RII was used by Odusami (2002) to rank the skills of effective project leaders as perceived by Construction Professionals, while others (Enshassi, Mohamed, \& El Karriri, 2010) used the RII to rank factors affecting the Bid/No Bid Decision in the Palestinian construction industry and was used by Fugar and Agyakwah-Baah (2010) to rank delay factors in construction projects in Ghana.

The data were subjected to various tests including reliability test, validity test, normality test, Spearman's Rank Co-efficient test and finally the RII was used to rank the factors to reveal the most important factors as perceived by the respondents. In order to examine the agreement in ranking of the important factors between public and private sector delegates, the Spearman Rank Correlation Test was conducted. The Spearman Rank Correlation Coefficient maybe employed as a test statistic to test a hypothesis of no association/no agreement between pairs of measurements from two populations. For a given value of alpha (level of significance) and for a two-tailed test, the rejection region of null hypothesis $\left(H_{o}\right)$ occurred if $r_{s} \geq r_{o}$ or if $r_{s} \leq-r_{o}$, where rho is the critical value of Spearman's Rank Correlation Coefficient (Mendenhall, Reinmuth, \& Beaver, 1993). The degree of agreement is expressed as a "correlation coefficient". The rank correlation coefficient $\left(r_{s}\right)$ is represented by the equation:

$$
\rho=1-\frac{6 \sum d^{2}}{n\left(n^{2}-1\right)}
$$

where " $d$ " is the difference between the ranks indicated by public and private sector delegates for each benefit, and " $n$ " is numbers of benefits $(n=20)$.

\section{Results and Discussion}

The results reveal that 8 of the respondents were delegates from Africa, 27 were from Australasia (a grouping of Asia and Australia), 6 from the Middle East, 1 delegate from Europe and 2 delegates from North America all participated in the survey. In terms of sector, 28 of the delegates were from the public sector while 16 were 
employed in the private sector. The reliability test carried out on the data returned a Cronbach's alpha of 0.947 , using the guide provided by George and Mallery (2003) an alpha greater than $0.9=$ Excellent; greater than $0.8=$ Good; greater than $0.7=$ Acceptable; greater than 0.6 = Questionable; greater than $0.5=$ Poor; less than 0.5 Unacceptable. From the guide above, it shows that the data collection instrument was reliable. In terms of validity, a generally accepted rule of thumb for explaining construct validity was provided by Hinton et al. (2004) who pointed out a validity test score of more than 0.90 is statistically considered excellent; $0.70-0.90$ is high, 0.5-0.7 is moderate while below 0.50 indicates a low validity rate of the variables, meaning that the questionnaire did not measure what it was constructed to measure. For this data, the average extracted value obtained was 0.78 which indicates a high overall validity of the data; hence, the high validity value obtained is a clear indication that the questionnaire measured what it was constructed to measure (Dewberry, 2004). On the correlation in terms of ranking between the two sectors, it was found to be positively significant with a Spearman's Correlation Coefficient of $(r h o) \rho=0.68$. The strength of the relationship fell within the strongperfect classification (Cohen, 1992).

Table 1. Relative importance index (RII) of the perceived benefits of PFI as ranked by respondents

\begin{tabular}{|c|c|c|c|c|c|c|}
\hline \multicolumn{7}{|c|}{ RII for public and private sector stakeholders' ranking of PFI benefits } \\
\hline & Perceived Benefits of PFI/PPP & $\begin{array}{l}\text { Public } \\
\text { Sector }\end{array}$ & Ranking & $\begin{array}{l}\text { Private } \\
\text { Sector }\end{array}$ & Ranking & $\begin{array}{l}\text { Overall } \\
\text { Ranking }\end{array}$ \\
\hline 1 & $\begin{array}{l}\text { Help government spread payment over life of } \\
\text { asset }\end{array}$ & 0.81 & 2 & 0.78 & 1 & 0.80 \\
\hline 2 & Increased investments in infrastructure & 0.80 & 5 & 0.78 & 2 & 0.79 \\
\hline 3 & On-time delivery of assets & 0.79 & 6 & 0.76 & 3 & 0.78 \\
\hline 4 & Contribution to economic growth & 0.82 & 1 & 0.74 & 4 & 0.78 \\
\hline 5 & On-budget delivery of assets & 0.77 & 13 & 0.74 & 5 & 0.76 \\
\hline 6 & Encouraging more innovative public sector & 0.79 & 7 & 0.73 & 6 & 0.76 \\
\hline 7 & Improved business confidence & 0.81 & 3 & 0.71 & 7 & 0.76 \\
\hline 8 & Reduce pressure on public budget & 0.79 & 8 & 0.71 & 8 & 0.75 \\
\hline 9 & Help get around public sector debt restriction & 0.71 & 19 & 0.71 & 9 & 0.75 \\
\hline 10 & Overcoming design and construction risks & 0.79 & 9 & 0.70 & 10 & 0.75 \\
\hline 11 & Greater innovation in service delivery & 0.79 & 10 & 0.70 & 11 & 0.75 \\
\hline 12 & Improved efficiency through more competition & 0.81 & 4 & 0.69 & 12 & 0.74 \\
\hline 13 & Better accountability & 0.79 & 11 & 0.69 & 13 & 0.74 \\
\hline 14 & Boost sale of professional PFI services abroad & 0.74 & 15 & 0.69 & 14 & 0.72 \\
\hline 15 & Contribute to fiscal stabilisation & 0.73 & 18 & 0.69 & 15 & 0.71 \\
\hline 16 & Helps achieve technology transfer & 0.79 & 12 & 0.68 & 16 & 0.71 \\
\hline 17 & Provide better value for money & 0.74 & 16 & 0.68 & 17 & 0.71 \\
\hline 18 & Improves governance & 0.76 & 14 & 0.66 & 18 & 0.71 \\
\hline 19 & Better access and affordability for end-users & 0.74 & 17 & 0.65 & 19 & 0.70 \\
\hline 20 & Helps eliminate corruption & 0.71 & 20 & 0.59 & 20 & 0.65 \\
\hline
\end{tabular}

Table 1 above shows the factors which have been ranked using their RII values. The responses by the public sector and private sector were assessed differently and later an overall ranking was carried out based on the responses of the delegates. As can be seen from the table, the public sector ranked 'contribution to economic growth' $(\mathrm{RII}=0.82)$ as the most significant contribution so far of the PFI procurement strategy, while according to the private sector respondents, 'helping government spread payment over the life of the assets' was considered as the most significant contribution of the PFI strategy so far. However, when the overall ranking was performed, 'helping government spread payment over the life of the assets' received the highest RII value $(\mathrm{RII}=0.80)$. This 
finding is particularly significant given the fact that 'value for money' which is hyped by most proponents of the PFI was among the benefits but was surprisingly ranked $16^{\text {th }}$ and $17^{\text {th }}$ place by the public and private sector respondents respectively. What this implies is that both sectors may have now realized that the PFI is not delivering what it exactly set out to do. This much has been admitted to by IMF which together with the World Bank has been a fervent advocate of PFI, they observed that "much of the case for PPP rests on the relative efficiency of the private sector. While there is an extensive literature on this subject, the theory is ambiguous and the empirical evidence is mixed" (IMF, 2004). Increased investment in infrastructure (RII $=0.79)$ was ranked at $2^{\text {nd }}$ place consistent with the argument of Parker and Hartley (2003) that PFI helps provide infrastructure faster than would have been possible relying on government finance alone. The 'contribution to economic growth' and 'on-time Delivery tied at $3^{\text {rd }}$ place as the next most important benefit being achieved through the PFI. This is understandable since infrastructure development has been shown to have a positive impact on economic growth (Thanh \& Dapice, 2009; World Bank, 2007). 'On-budget delivery', 'evolution of an innovative public sector' and 'improving business confidence' all tied with an RII value of 0.76 . However, the factor worth commenting on is the 'on-budget delivery' which was ranked in $13^{\text {th }}$ place by the public sector respondents and $5^{\text {th }}$ place by the private sector respondents. This is particularly interesting considering the fact that the private sector being advocates and beneficiaries of the PFI tend to affirm contrary to available evidence (Mehra, 2005; Pollock, Shaoul, \& Vickers, 2002) that the PFI delivers on budget. But the public sector, which is aware of the real situation relating to PFI performance have ranked this factor in faraway $13^{\text {th }}$ place. This means that, if we were to use the median value to divide the factors, as ranked by the public sector alone, into two parts the tendency exist that 'on-budget delivery' will not be among the most important benefits being achieved under the PFI. This is another significant finding considering the fact that Sciulli (2007) argues that "under the traditional procurement methods, governments had to contend with the risk of significant cost overruns for large infrastructure projects. This risk is now mitigated under the PPP as the private sector partner assumes this risk". The most significant finding that ran contrary to the perceived notion of PFI advocates is the ranking of 'Value for money' which is one of the major pillars upon which the PFI rests. The public sector ranked this factor in $16^{\text {th }}$ place while surprisingly the private sector ranked it in $17^{\text {th }}$ place while it achieved an overall ranking of $17^{\text {th }}$ place out of 20 other benefits. It appears that there has been a self-appraisal and the need to protect reputation by the private sector resulting in the ranking of this benefit in the $17^{\text {th }}$ position. On the part of the public sector, the experiences on many PFI have not been really pleasant, the constant calls for re-negotiations, the disputes and delays clearly means that value for money is not being achieved on most of the PFI projects globally. This is consistent with the arguments put forward by Pollock et al. (2002) and Hodge and Greve (2009) that so far the evidence of value for money on current PFI projects cannot really stand up to public scrutiny. 'Affordability for end-users' and 'help eliminate corruption' were ranked $19^{\text {th }}$ and $20^{\text {th }}$ place respectively, meaning that among the benefits that have been achieved, these could not be said to have been achieved. These suggest that new forms of corruption have evolved with the PFI to replace the former channels employed during the reign of the traditional procurement method. Surprisingly, both sector ranked 'help eliminates corruption in the $20^{\text {th }}$ place and this turned out to be the only factor whose position both sectors converged in terms of ranking.

\section{Conclusions}

The PFI has been harped as being able to provide value for money (VFM) to the public sector by providing cheaper and more efficient public services. It is also believed to help provide infrastructure faster than would have been possible relying solely on public sector finances. However, the results of this study while not disputing these claims entirely seem to suggest that presently these supposed benefits have not been achieved according to the importance given to the factors by the respondents in this study. Instead the results reveal that, the major benefit that has been achieved so far is that it assists the government in spreading payment for infrastructure over the life of the project reducing the pressure of huge upfront payments which could have a huge effect on the public sector finances. The implication of this is that, the public sector would have to reappraise its reasons and re-assess its policy direction with regard to the use of PFI. For if this is the major reason, it would be better to adopt a design and build strategy while providing the financing since it is cheaper for the public sector to borrow than the private sector. The VFM which has underpinned the PFI has been shown not to be achieved as perceived by the respondents. There is a need for a re-appraisal of the current state of the PFI so as to ascertain why VFM is not being achieved. The result might have been different if we had access to real data from operational PFI projects to compare with projects being undertaken under the traditional procurement method. But the entire PFI practice across the globe without exception is shrouded in secrecy. It is still a wonder how the private sector was able to convince the public sector to accept to hide data and documents which ordinarily should be in the public domain from the general public. Interestingly, it would seem that this is done to forestall further criticism of the process because the more information is available in the public sphere; 
the more 'weapons' that are provided to those opposed to the PFI strategy to attack the policy. The government still owe its citizens, practitioners, and researchers the duty of accountability and transparency, so that when these information are available, researchers would be able to assess and come up with better alternative methods of providing public services without inviting the controversies that presently surround the practice of the PFI.

\section{Implication for Practice}

From the results obtained above, it has become important for the proponents of the strategy to articulate the real reasons for adopting this expensive approach for the provision of public infrastructure and services in order to gain the support of the numerous stakeholders. The support of the tax-paying public has been shown in recent months to be a critical determinant to the success or otherwise of any government initiative.

\section{Acknowledgements}

This work was supported by the Exploratory Research Grant Scheme (ERGS) of the Ministry of Higher Education Malaysia and the facilities made available at the Universiti Teknologi PETRONAS. We are also grateful to the 2 anonymous referees for their helpful comments and guidance.

\section{References}

Abdul-aziz, A. R. (2001). Unraveling Of Bot Scheme: Malaysia's Indah Water Konsortium. Journal of Construction Engineering and 457-460. http://dx.doi.org/10.1061/(ASCE)0733-9364(2001)127:6(457)

Abdul Rashid, K. (2007). Private Finance Initiative (PFI): Concept and Method of Procurement for Construction Projects (with specific refference to Malaysia). Kuala Lumpur: IIUM.

Aibinu, A., \& Jagboro, G. (2002). The effects of construction delays on project delivery in Nigerian construction industry. International Journal of Project Management, 20, 593-599. http://dx.doi.org/10.1016/S0263-7863(02)00028-5

Ali, A. S., Smith, A., Pitt, M., \& Choon, C. H. (2010). Contractors' Perception Of Factors Contributing To Project Delay: Case Studies Of Commercial Projects In Klang Valley, Malaysia. Journal of Design and Built Environment, 6(2).

Asenova, D., \& Beck, M. (2010). Crucial Silences: When accountability met PFI and Finance Capital. Critical Perspectives on Accounting, 21, 1-13. http://dx.doi.org/10.1016/j.cpa.2008.09.009

Assaf, S. A., \& Al-Hejji, S. (2006). Causes of delay in large construction projects. International Journal of Project Management, 24, 349-357. http://dx.doi.org/10.1016/j.ijproman.2005.11.010

Bank, W. (2007). The Growth Report. Washington D.C.: World Bank Growth Commission.

Blanc-Brude, F., Goldsmith, H., \& Välilä, T. (2009). A Comparison of Construction Contract Prices for Traditionally Procured Roads and Public-Private Partnerships. Review of Industrial Organisations, 35, 19-40. http://dx.doi.org/10.1007/s11151-009-9224-1

Budds, J., \& McGranahan, G. (2003). Are the debates on water privatization missing the point? Experiences from Africa, Asia and Latin America. Environment \& Urbanization, 15(2), 87-113.

Cartlidge, D. (2004). Procurement of Built Assets. Oxford: Elsevier Butterworth-Heinemann.

Cohen, J. (1992). A Power Primer. Psychological Bulletin, 112(1), 155-159. http://dx.doi.org/10.1037/0033-2909.112.1.155

Cohn, D. (2008). The New Public Autonomy? Public Private Partnerships in a Multi-level, MultiAccountable, Political Environment: The case of British Columbia, Canada. Policy and Society, 27, 29-42. http://dx.doi.org/10.1016/j.polsoc.2008.07.003

Connoly, C., Reeves, E., \& Wall, A. (2009). Isomorphism: An Explanation For The Popularity Of Public-Private Partnership? The Irish Accounting Review, 16(1).

Corner, D. (2006). The United Kingdom Private Finance Initiative: The Challenge of Allocating Risk. OECD JOURNAL ON BUDGETING, 5(3), 37-53 .

Dewberry, C. (2004). Statistical Methods for Organizational Research. Routledge. http://dx.doi.org/10.4324/9780203414897 
Enshassi, A., Mohamed, S., \& El Karriri, A. (2010). Factors Affecting the Bid/No Bid Decision in the Palestinian Construction Industry. Journal of Financial Management of Property and Construction, 15(2). $\mathrm{http}: / / \mathrm{dx}$.doi.org/10.1108/13664381011063421

Estache, A. (2005). PPI partnerships versus PPI divorces in LDCs: (or are we switching from PPPI to PPDI?). Washington D.C.: World Bank. http://dx.doi.org/10.1596/1813-9450-3470

Fugar, F. D., \& Agyakwah-Baah, A. B. (2010). Delays in building construction projects in Ghana. Australasian Journal of Construction Economics and Building, 10(1/2), 103-116.

George, D., \& Mallery, P. (2003). SPSS for Windows step by step: A simple guide and reference. 11.0 update (4th ed.). Boston: Allyn \& Bacon.

Haynes, P. (2003). Managing complexity in the Public Services. Glasgow, London : Bell \& Bain Ltd.

Hinton, P., Brownlow, C., McMurray, I., \& Cozens, B. (2004). SPSS Explained. United Kingdom: Routledge.

Hinze, J. (2001). Construction Contracts (2nd ed.). United States: McGraw-Hill.

Hodge, G. A., \& Greve, C. (2005). The Challenge of Public-Private Partnerships: Learning From International Experience. Cheltenham UK: Edward Elgar Publishing.

Hodge, G. A., \& Greve, C. (2009). PPPs:The Passage of Time Permits a Sober Reflection. Economic Affairs, 29(1), 33-39.

IMF. (2004). Public-Private Partnerships. Washington D.C.: International Monetary Fund.

KPMG. (2010). The Changing Face of Infrastructure: Public sector perspectives. The UK: KPMG International.

Latham, M. (1994). Constructing the Team. London: HMSO.

Li, B., Akintoye, A., Edwards, P., \& Hardcastle, C. (2005). Perceptions of Positive and Negative factors influencing the attractiveness of PPP/PFI Procurement for Construction Projects in the UK: Findings from a questionnaire survey. Engineeering, Construction and Architectural Management, 12(2), 125-148.

Maltby, P. (2003). Comparing Cost. Retrieved from http://www.publicservice.co.uk/pdf/pfi/summer2003/pj41\%20paul\%20maltby\%20atl.pdf

Mehra, N. (2005). Flawed, Failed, Abandoned, 100 P3s: Canadian and International Evidence. Ontario: Ontario Health Coalition.

Mendenhall, W., Reinmuth, J., \& Beaver, R. (1993). Statistics for Management and Economics. California: Duxbury Press.

NAO. (2001). Modernising Construction. London: National Audit Office.

NAO. (2009). Performance of PFI Construction. London: National Audit Office.

Nickson, A., \& Vargas, C. (2002). The Limitation of Water Regulation: The Failure of the Cochabamba Concession in Bolivia. Bulletin of Latin American Research, 21(1), 99-120. http://dx.doi.org/10.1111/1470-9856.00034

Odusami, K. T. (2002). Perceptions of Construction Professionals Concerning Important Skills of Effective Project Leaders. Journal of Management in Engineering, 18, 61-67. http://dx.doi.org/10.1061/(ASCE)0742-597X(2002)18:2(61)

Palmer, K. (2000). Contract issues and Financing in PPP/PFI (Do we need the 'F' in DBFO projects). UK: Institute For Public Policy Research (IPPR) Commission of Public Private Partnerships.

Parker, D., \& Hartley, K. (2003). Transaction Costs,Relational Contracting and Public Private Partnerships: A Case Study of UK Defence. Journal of Purchasing and Supply Management, 9, 97-108. http://dx.doi.org/10.1016/S0969-7012(02)00035-7

Pollock, A., Shaoul, J., \& Vickers, N. (2002). Private Finance and "Value for Money" in NHS Hospitals: A Policy in Search of a Rationale? British Medical Journal, 324, 1205-1209. http://dx.doi.org/10.1136/bmj.324.7347.1205

Pourrostam, T., \& Ismail, A. (2011). Significant Factors Causing and Effects of Delay in Iranian Construction Projects. Australian Journal of Basic and Applied Sciences, 5(7), 450-456. 
Proverbs, D., Holt, G., \& Olomoaiye, P. (1999). European construction contractors: a productivity appraisal of in-situ concrete operations. Journal of Construction Management and Economics, 17(1), 221-230. http://dx.doi.org/10.1080/014461999371727

Sambasivan, M., \& Soon, Y. (2007). Causes and Effects of Delays in Malaysian Construction Industry. $\begin{array}{llll}\text { International Journal of Project } & \text { Management, }\end{array}$ http://dx.doi.org/10.1016/j.ijproman.2006.11.007

Sciulli, N. (2007). Public private partnerships: Identifying practical issues for an Accounting Research Agenda. Journal of Business Systems, Governance and Ethics, 2(2), 17-28.

Shaoul, J., Stafford, A., \& Stapleton, P. (2012). Accountability and Corporate Governance of public private

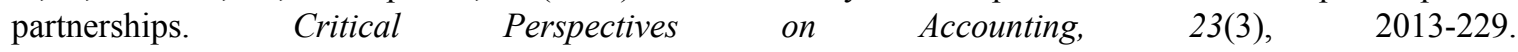
http://dx.doi.org/10.1016/j.cpa.2011.12.006

Siang, L. Y. (2008). Private Finance Initiatives-Infrastructure and utilities Development. The Ingenieur Journal, $36,6-9$.

Thanh, N. X., \& Dapice, D. (2009). Vietnam's Infrastructure Constraints. Cambridge: United Nations Development Programme.

The Commission on PPP. (2001). Building Better Partnerships. London: Institute of Public Policy Research.

Thomson, C., \& Goodwin, J. (2005). Evaluation of PPP projects financed by the EIB. Luxembourg: European Investment Bank.

UNISON Scotland. (2007). AT What Cost? Scotland: UNISON Scotland.

Webster, J., \& Watson, R. T. (2002). Analyzing The Past To Prepare For The Future: Writing A Literature Review. MIS Quarterly, 26(2), xiii-xxiii.

Zhang, Q., \& Kumaraswamy, M. (2001). Hong Kong Experience in Managing BOT Projects. Journal of $\begin{array}{lcrrr}\text { Construction } & \text { Engineering } & \text { Management, } & 127(2), & 154-162 .\end{array}$ http://dx.doi.org/10.1061/(ASCE)0733-9364(2001)127:2(154) 